\title{
BUKU MODEL \\ MOBILE COUNSELLING ONLINE
}

\author{
Dr. Eni Fariyatul Fahyuni, M.Pd.I \\ Dr. Retno Tri Hariastutik, M.Pd. Kons \\ Cindy Taurusta, S.ST, M.T
}

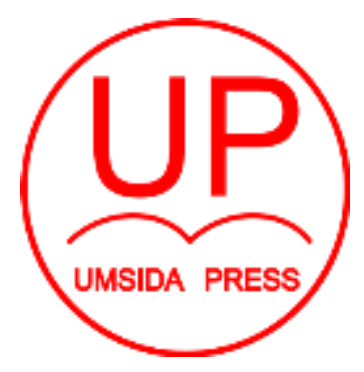

Diterbitkan oleh

\section{UMSIDA PRESS}

J1. Mojopahit 666 B Sidoarjo

ISBN: 978-623-6292-12-9

Copyright@2021.

Authors

All rights reserved 


\section{BUKU MODEL}

\section{MOBILE COUNSELLING ONLINE}

\section{Penulis :}

Dr. Eni Fariyatul Fahyuni, S,Psi, M.Pd.I

Dr. Retno Tri Hariastutik, M.Pd. Kons

Cindy Taurusta, S.ST, M.T

ISBN : 978-623-6292-12-9

\section{Editor :}

M. Tanzil Multazam,S.H.,M.Kn

Mahardika Darmawan K.W.,S.Pd,.M.Pd

\section{Copy Editor :}

Wiwit Wahyu Wijayanti

\section{Design Sampul dan Tata Letak :}

Wiwit Wahyu Wijayanti

\section{Penerbit :}

UMSIDA PressRedaksi :

Universitas Muhammadiyah Sidoarjo

Jl. Mojopahit No 666B

Sidoarjo, Jawa TImur

Cetakan pertama, Juli 2021

(C) Hak cipta dilindungi undang-undang

Dilarang memperbanyak karya tulis ini dengan suatu apapun tanpa ijin tertulis dari penerbit. 


\section{KATA PENGANTAR}

Puji syukur kami panjatkan ke hadirat Allah SWT, atas rahmat, karunia, dan kehendak-Nya, buku model mobile counselling online (MCO) dapat diselesaikan dengan baik meskipun perlu penyempurnaan lebih lanjut. Sholawat dan salam semoga selalu tercurahkan kepada junjungan Rasulullah Muhammad SAW.

Buku model mobile counselling online sangat dibutuhkan dalam memetakan potensi masing-masing individu dalam rangka merancang strategi belajar efektif siswa yang sesuai dengan kebutuhan dan karakteristik yang dimilikinya.

Dengan selesainya penulisan buku model ini penulis mengucapkan terima kasih kepada semua pihak yang telah memberikan bahan-bahan tulisan baik langsung maupun tidak langsung. Penulis juga mengucapkan terima kasih khususnya kepada:

1. Dr. Hidayatullah, M.Si pemangku pimpinan tertinggi yaitu Rektor Universitas Muhammadiyah Sidoarjo yang telah memberikan dan memfasilitasi dalam penulisan buku model ini.

2. P3iK Universitas Muhammadiyah Sidoarjo yang telah memfasilitasi dan mengkoordinasi dalam penulisan buku buku model mobile counselling online.

3. Dr. Istikomah, M.Ag. sebagai Dekan Fakultas Agama Islam, Universitas Universitas Muhammadiyah Sidoarjo yang telah memberikan dukungan untuk mengikuti penulisan buku model mobile counselling online. 
4. Para narasumber, dosen serta teman-teman mahasiswa $S 1 \&$ S2 bidang konsentrasi pendidikan di lingkungan Fakultas Agama Islam, Universitas Muhammadiyah Sidoarjo yang telah banyak membantu atas penyusunan penulisan buku model ini.

Akhir kata, kritik dan saran sangat diharapkan untuk penyempurnaan buku ajar ini. Harapan kami semoga buku model mobile counselling online ini dapat digunakan sebagai tambahan informasi dan bermanfaat bagi aktivitas pembelajaran di Fakultas Agama Islam, Universitas Universitas Muhammadiyah Sidoarjo.

Penulis. 


\section{DAFTAR ISI}

Cover

Identitas Buku

Kata Pengantar

Batang Tubuh

\section{Bab I : Pendahuluan}

A. Rasional Model MCO

B. Bimbingan Konseling Online

C. Fungsi Bimbingan dan Konseling Online

Bab II : Karakteristik Peserta Didik

A. Karakter Individu

B. Belajar dan Peserta Didik

Bab III : Konseling Online Berbasis Android
A. Mobile Counselling Online
B. Tahapan Pelaksanaan MCO
C. Motivasi Berprestasi
D. Komunikasi Via Internet

Daftar Pustaka 


\section{BAB I \\ PENDAHULUAN}

\section{A. Rasional Model Mobile Counselling Online}

Seiring perkembangan teknologi informasi di era revolusi industry 4.0 menuntut berbagai pihak khususnya dunia pendidikan untuk harus mampu beradaptasi dengan perkembangan teknologi digital. Hal ini merujuk rencana strategis penelitian dan abdimas UMSIDA kurun waktu 2016 - 2020 yaitu pada pengembangan Iptek berbasis potensi lokal menuju Indonesia berkemajuan, maka urgensi penelitian ini adalah berkontribusi positif bagi pengembangan ilmu pengetahuan dan teknologi guna kemudahan akses layanan bagi para peserta didiknya.

Beberapa aplikasi layanan konseling online yang saat ini tersedia, sebagian besar hanya memfokuskan pada penanganan masalah karier, personal, sosial dan keluarga. Layanan bimbingan dan konseling di sekolah belum memiliki dan menggunakan aplikasi layanan bimbingan konseling online yang berorientasi pada layanan informasi dan pembelajaran memaksimalkan pemahaman potensi diri siswa melalui pengenalan (gaya belajar, kecerdasan majemuk dan yang lainnya) untuk seseorang merancang strategi belajar bagi peningkatan motivasi berprestasinya di sekolah.

Perkembangan jaman hingga sampai pada masa revolusi industri 4.0 telah mendunia secara luas dalam perkembangan dunia industri (Kinzel, 2016). Istilah 4.0 memiliki perspektif makna bahwa dunia telah memasuki suatu perubahan dan perkembangan diberbagai bidang utamanya bidang industri yang sangat pesat yang 
diberi istilah penyebutan "Revolusi Industri 4.0". istilah dan konsep revolusi industri 4.0 memang belum banyak dipahami sejumlah kalangan, namun peluang perubahan dan perkembangannya merebak ke seluruh penjuru dunia, merubah tatanan dan pola pikir dan berbagai aspek kehidupan manusia di segala bidang.

Revolusi industry 4.0 merupakan tahapan keberlanjutan dari perkembangan tiga revolusi industri sebelumnya. Sebagian besar masyarakat bahkan mempersepsikan definisi revolusi industri sebagai perubahan dinamis yang terjadi akibat adanya system perubahan metode produksi di bidang perusahaan yang sudah mulai mengarah pada penggunaan mesin uap. Sesungguhnya revolusi industry ini terjadi sejak pertama kali ditemukannya mesin tenun tahun 1784 . Mesin inilah yang merubah metode produksi yang awalnya hanya dilakukan secara manual, selanjutnya telah diganti menggunakan tenaga mesin yang lebih efisien penggunaannya karena dapat dilakukan dalam skala besar.

Revolusi industri kedua akhirnya terus berkembang antara abad ke-19 hingga awal abad ke-20 beriringan bermunculnya penggunaan tenaga listrik. Perubahan ini memiliki karakteristik pada jalur perakitan (assembly line) dan produksi massal (mass production). Pada periode inilah berbagai perubahan dan penggunaan alat elektronik dan IT telah mensupport produksiproduksi pabrik dan dunia industry semakin menggeliat. Dengan kita berupaya memahami berbagai perubahan dan tantangan era revolusi industri 4.0 yang semakin dinamis dan begitu cepat utamanya pada perkembangan media teknologi dan internet di era digital. 


\section{B. Bimbingan Konseling Online}

Bimbingan merupakan suatu hal yang amat sangat penting bagi perkembangan para siswanya. Siswa adalah individu yang berharga calon pemimpin masa depan. Oleh karenanya mereka perlu dihormati, diakui keberadaan dan beragam potensi yang dimilikinya. Pembimbing hendaknya menunjukkan sikap emphati dan perhatiannya kepada klien, agar pembimbing menunjukkan perhatiannya untuk menumbuhkan rasa percaya dirinya dan aktualisasi potensi yang dimilikinya.

Konseling merupakan salah satu teknik dalam pelayanan bimbingan di antara beberapa teknik lainnya, Bimbingan sifatnya lebih luas, konseling merupakan alat yang paling penting dari usaha pelayanan bimbingan (E. et al. Fahyuni, 2020). Konseling merupakan teknik dalam pelayanan bimbingan dimana proses pemberian bantuan itu berlangsung antara pembimbing/konselor dengan klien baik tatap muka maupun non tatap muka (online). Layanan bimbingan dan konseling daring berbentuk website/situs, telephone/handphone, email, chat, instant messaging, jejaring sosial dan video conferencing (Putri, 2020) (E. F. Fahyuni et al., 2020). Bimbingan dan konseling bertujuan agar klien itu memahami dirinya lebih baik dari sebelumnya agar menjadi lebih berakhlakul karimah sesuai nilai-nilai Islam dalam memecahkan masalahnya (E. Fahyuni, 2018). 


\section{Fungsi Bimbingan dan Konseling Online}

Bimbingan yang diberikan di sekolah memiliki fungsi diantaranya: sebagai preventife (pencegahan), sebagai kuratif/korektif, sebagai preservative (penjagaan), sebagai pengembangan (developmental), sebagai distributive (penyaluran), sebagai adaptif dan adjustive (penyesuaian). Bimbingan dan konseling online adalah rangkaian program pelayanan secara online atau jarak jauh yang dilakukan kepada peserta didik maupun konseli agar dapat mengembangkan diri kearah yang lebih positif.

Bimbingan konseling dapat diselenggarakan dilingkungan sekolah maupun di lingkungan masyarakat umum. Fungsi dari bimbingan konseling itu sendiri yakni pemahaman, pencegahan, pengentasan, peralihan, dan pemeliharaan (E. Fahyuni, 2018). Pemahaman yang dimaksud adalah terkait dengan lingkungan sekitar, lingkungan sekolah, lingkungan masyarakat maupun lingkungan keluarga. Pencegahan yakni menghindari masalahmasalah yang mungkin akan terjadi dengan melalui bimbingan. Pengentasan dapat meminimalisir masalah-masalah yang di hadapi konseli, sedangkan pemeliharaan yakni kondisi positif yang menjamin perkembangan pada konseli.

Hasil riset menunjukkan bahwa layanan e-konseling sangat efektif digunakan dalam pemberian layanan dengan keterbatasan waktu dan jarak yang dapat diatur sesuai dengan kondisi guru ataupun kliennya melalui media WhatsApp yang terdiri dari banyak fitur didalamnya seperti videocall, story WhatsApp, pesan WhatsApp dan yang lainnya (Sugiarti, 2020). 


\section{BAB II \\ KARAKTERISTIK PESERTA DIDIK}

\section{A. Karakteristik Individu}

Karakteristik individu merupakan keseluruan perilaku dan kemampuaan individu yang merupakan bagian dari pembawaan dan lingkungannya. Karateristik individu identic dengan sifat khas seseorang yang dimilikinya sejak kecil atau sejak dilahirkan. Dengan pemahaman atas karakteristik individu, guru dapat merekonstruksi dan mengorganisasikan materi pelajaran sedemikian rupa, memilih dan menentukan metode yang tepat, sehingga terjadi proses interaksi dari masing-masing komponen secara optimal (Abu, Lukman; Mokhtar, Mahani; Hassan, 2015).

Kemampuan penyesuaian diri secara pribadi dan sosial sangat erat kaitannya dengan kelompok teman sebayanya. Teman sebaya ini merupakan hal terpenting yang merupakan tempat belajar hidup bersama orang lain (de Ruiter et al., 2019). Lingkungan teman sebaya secara tidak langsung menuntut seseorang untuk dapat menyesuaikan diri dan menjalin interaksi sosial. Hasil riset menunjukkan semakin sering remaja terlibat dalam aktivitas sosial maka akan semakin meningkatkan kompetensi diri dan rasa percaya diri (Schleicher, 2012). 


\section{B. Belajar dan Peserta Didik}

Belajar adalah salah satu topik terpenting dalam psikologi saat ini, tetapi konsepnya sulit untuk didefinisikan. Selama beberapa tahun terakhir telah ada kecenderungan untuk menerima definisi belajar yang mengacu pada perubahan perilaku yang dapat diamati. Belajar adalah suatu proses usaha yang dilakukan oleh seseorang untuk memperoleh suatu perubahan tingkah laku yang baru secara keseluruhan sebagai hasil dari pengalamannya sendiri dalam berinteraksi dengan lingkungannya. Belajar adalah proses mengubah perilaku atau kepribadian seseorang berdasarkan praktik atau pengalaman tertentu. Ketika orang belajar, responnya menjadi lebih baik. Di sisi lain, jika dia tidak belajar, responsnya akan berkurang

Masalah dalam mendidik siswa adalah masalah yang dihadapi setiap para guru dan orangtua di rumah. Setiap orang boleh dikatakan melakukan kegiatan berupa belajar sekaligus mengajar. Belajar pada hakekatnya adalah suatu proses interaksi terhadap semua situasi baru yang ada di sekitar kita. Belajar dapat dipandang sebagai proses yang diarahkan guna pencapaian target yang dicita-citakan (Hosnan, 2014).

Mengajar harus terkait dengan makna belajar yang perlu memahami prinsip belajar yang ada pada diri siswa. Dengan demikian kegiatan pembelajaran menuntut terwujudnya multiperan pendidik, yang tidak hanya fokus menyampaikan pengetahuan dan mentransfer keterampilan, dan merupakan satusatunya sumber belajar, tetapi perlu menjelma menjadi 
pembimbing, pembina, pengajar dan pembina. yang berarti mengajar siswa. Belajar di masa pandemic COVID-19 berdasarkan hasil riset menunjukkan pembelajaran online dengan didukung sarana dan fasilitas yang mendukung mampu mendorong munculnya kemandirian belajar dan motivasi belajar dan meminimalisir munculnya keramaian dapat mengurangi potensi penyebaran Covid-19 (Rahman, 2020).

Kesulitan belajar menjadi salah satu masalah dalam proses belajar yang ditandai dengan berbagai perilaku yang memiliki latar belakang di dalam dan di luar peserta didik. Beberapa perilaku tersebut antara lain: menunjukkan hasil belajar yang rendah; hasil yang dicapai tidak seimbang dengan upaya yang telah dilakukan; lambat dalam mengerjakan tugas-tugas kegiatan pembelajaran; menunjukkan sikap yang tidak pantas; menunjukkan perilaku abnormal, seperti membolos, datang terlambat, tidak mengerjakan pekerjaan rumah (PR), mengganggu di dalam atau di luar kelas, dan sebagainya; serta menunjukkan gejala emosional yang tidak wajar. Untuk itu sekolah perlu terus berbenah dan mengembangkan sekolah yang sesuai dan memenuhi hak-hak anak, yang memberikan kenyamanan dan keamanan bagi para siswanya (de Ruiter et al., 2019). Kebutuhan belajar siswa tidaklah lepas satu sama lain melainkan sebagai suatu keseluruhan yang dapat mendorong proses belajarnya. Oleh karenanya seorang pendidik harus dapat mengenal kebutuhan dan karakteristik anak didiknya. 


\section{BAB III \\ LAYANAN KONSELING ONLINE BERBASIS ANDROID}

\section{A. Mobile Counselling Online}

Seiring perkembangan teknologi informasi di era revolusi industry 4.0 menuntut berbagai pihak khususnya dunia pendidikan untuk harus mampu beradaptasi dengan perkembangan teknologi digital. Inovasi teknologi pada layanan bimbingan konseling diharapkan mampu meningkatkan self efficacy dan motivasi berprestasi siswa SMP \& SMA di Kabupaten Sidoarjo. Hasil riset menunjukkan layanan bimbingan konseling online terbukti efektif meningkatkan prestasi belajar siswa (Gozali, 2020) dengan siswa mampu problem solving dan mampu beradaptasi dengan lingkungan barunya (Yusuf, 2011).

Untuk itu diperlukan inovasi layanan bimbingan dan konseling online berbasis android yang mampu memfasilitasi kebutuhan, kenyaman dan kerahasiaan penggunanya. Komunikasi via internet saat ini telah menjadi bagian yang tak terpisahkan dari proses pengajaran (Koper, 2014). Salah satunya pada layanan konseling online yang semakin meluas dengan berbagai manfaatnya. Layanan bimbingan konseling daring yang selama ini diterapkan di masa pandemic COVID-19 belum dapat terlaksana dengan optimal dikarenakan keterbatasan fasilitas pendukung yang digunakan. Layanan berbasis cybercounselling yang selama ini banyak dikembangkan negara-negara maju di dunia internasional memiliki banyak kelebihan karena melibatkan penggunaan media elektronik sehingga dapat menjamin kerahasiaan kliennya. Inovasi 
layanan jarak jauh yang bersifat online tentunya harus mempertimbangkan desain, instruksi dan teknik penyampaian yang memperhatikan unsur estetika (Hernawati et al., 2018). Berikut merupakan roadmap penelitian pengembangan yang menghasilkan produk berupa mobile Counselling Online (MCO)

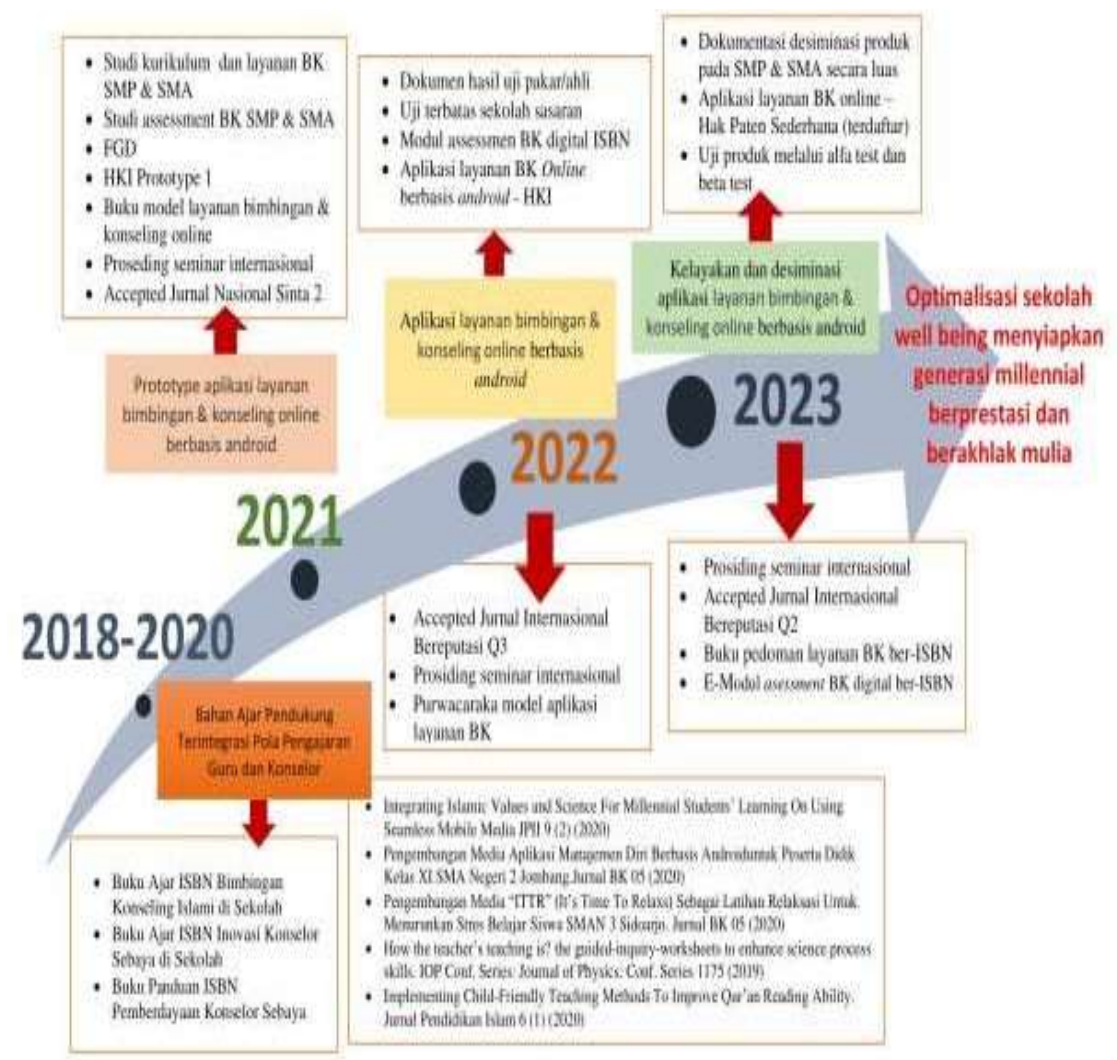

Gambar 1. Roadmap Penelitian 
Hasil penelitian menunjukkan peningkatan prestasi belajar siswa pada bidang studi Matematika dengan pola pengajaran guru dengan pendekatan multiple intelegence atau kecerdasan majemuk para siswanya [20]. Pengenalan potensi diri sangat penting bagi siswa agar mereka mampu menjawab permasalahannya sesuai karakteristik yang dimilikinya. Kemampuan merancang strategi belajar bagi tiap individu adalah tidak sama bagi setiap siswa, untuk itu siswa dapat dilibatkan merancang strategi belajar efektif sesuai potensinya.

Pemerintah kabupaten Sidoarjo menjadi salah satu kota yang telah berhasil membangun "Smart City" dengan mengintegrasikan berbagai aplikasi guna mendukung optimalisasi layanan kepada masyarakatnya sehingga layanan mudah diakses oleh para pengguna. Program layanan bimbingan konseling yang selama ini diterapkan di masa pandemic COVID-19 memiliki banyak kelemahan, salah satunya pada keterbatasan frekuensi bertemunya konselor dan klien di sekolah. Untuk itu diperlukan pembenahan layanan bimbingan konseling mobile untuk memudahkan akses siswa pada layanan bimbingan konseling jarak jauh.

Urgensi penelitian ini penting dilakukan dengan mempertimbangkan kebaruan dan kebermanfaatannya, yakni:

1. Identifikasi layanan bimbingan dan konseling online di sekolah sehingga tercipta plattfom aplikasi dengan fiturfitur yang mengakomodasi peningkatan self efficacy dan motivasi berprestasi. 
2. Terancangnya pengembangan aplikasi layanan bimbingan dan konseling online berbasis android yang mampu meningkatkan self efficacy dan motivasi berprestasi.

3. Aplikasi layanan bimbingan dan konseling online yang dihasilkan dapat membantu capaian generasi z yang memiliki self efficacy dan motivasi berprestasi yang tinggi. bagi siswa SMP \& SMA di Kabupaten Sidoarjo

\section{B. Tahapan Pelaksanaan MCO}

Waktu pelaksanaan penelitian ini direncanakan selesai yakni pada bulan Januari 2021 hingga Januari 2023. Tahun pertama, sebelum dirancang prototype layanan bimbingan konseling online berbasis android akan dilakukan FGD dengan melibatkan beberapa pengawas di dinas Pendidikan kabupaten Sidoarjo dan mengundang kepala sekolah serta koordinator guru BK untuk mengetahui tingkat pemahaman pada implementasi layanan bimbingan konseling online dan juga untuk mengetahui kesiapan support system layanan bimbingan dan konseling di masa pandemic COVID-19 sehingga dapat merumuskan prototype sesuai dengan yang ditargetkan. Tahun ke 2, mendesain prototype sekaligus ujicoba pengembangan produk pada sekolah sasaran. Tahun ke 3, dilakukan perbaikan aplikasi dan diperoleh hasil buku ajar BK, modul assessment BK digital, aplikasi layanan bimbingan konseling online berbasis android yang dapat desiminasikan secara luas pada siswa SMP dan SMA Kabupaten Sidoarjo. Berikut alur pelaksanaan penelitian yang direncanakan hingga 3 tahun kedepan. 
Menghasilkan model prototype layanan bimbingan dan konseling online berbasis android tersertifikat Hak Cipta

Menghasilkan buku model layanan bimbingan dan konseling online berbasis android ber-ISBN

\section{Prosiding Seminar Internasional}

Publikasi artikel jurnal Nasional Terakreditasi Sinta 2

Tahun kedua

Aplikasi layanan bimbingan dan konseling online berbasis android tervertifikat HKI

Purwacaraka model aplikasi layanan bimbingan dan konseling online berbasis android

Modul assessment bimbingan konseling digital ber-ISBN

Prosiding seminar internasional

Publikasi artikel di jurnal internasional Terindeks Scopus Q3

Tahun ketiga

Desiminasi penggunaan produk secara luas pada beberapa sekolah sasaran di Kabupaten Sidoarjo

Aplikasi layanan bimbingan dan konseling online berbasis android. Hak Paten Sederhana-Terdaftar

E-modul penggunaan aplikasi layanan bimbingan dan konseling online berbasis android ber-ISBN

Buku layanan bimbingan dan konseling SMP/SMA ber-ISBN

Prosiding seminar intemasional

Publikasi artikel di Jurnal Internasional Terindeks Scopus Q2

\section{Gambar 3. Target Luaran Penelitian}


Penelitian di tahun pertama, akan digunakan mix method. Hal ini perlu dilakukan guna menghasilkan prototype dari layanan bimbingan konseling online berbasis android. Jenis penelitian digunakan adalah expost facto.

\section{Tahun ke-1}

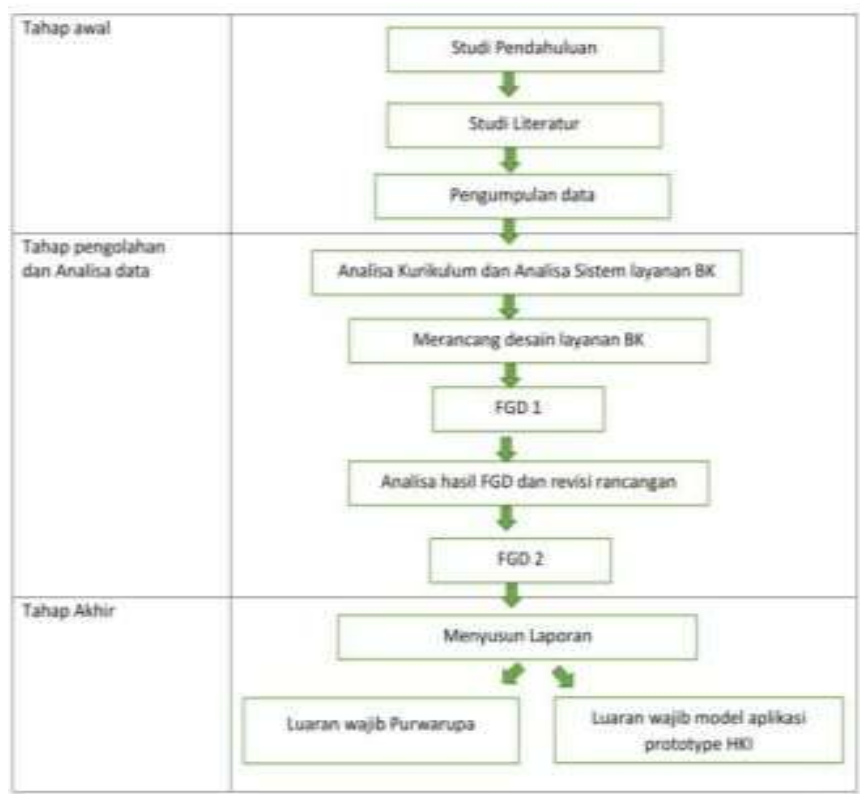

Data yang diperoleh dianalisis dengan menggunakan pendekatan kualitatif. Data dikumpulkan dengan menggunakan Focus Group Discussion dalam 2 sesi dimana setiap sesi dipandu dengan 3 tim fasilitator. Peneliti akan mendiskusikan dan memvalidasikan terkait prototype aplikasi layanan bimbingan dan konseling online berbasis android melibatkan para tim ahli yakni 
ahli media dan teknologi pembelajaran, kepala sekolah, waka kurikulum, dan koordinator BK di 6 (enam) SMP dan 4 (empat) SMA pada 5 (lima) Kecamatan, di Kabupaten Sidoarjo. Prototype ini berupa platform desain aplikasi yang mendukung layanan bimbingan dan konseling online berbasis android guna meningkatkan self efficacy dan motivasi berprestasi siswa SMP kelas VII, VII, dan IX, serta siswa SMA kelas X, XI, dan XII di Kabupaten Sidoarjo

\section{Tahun ke-2}

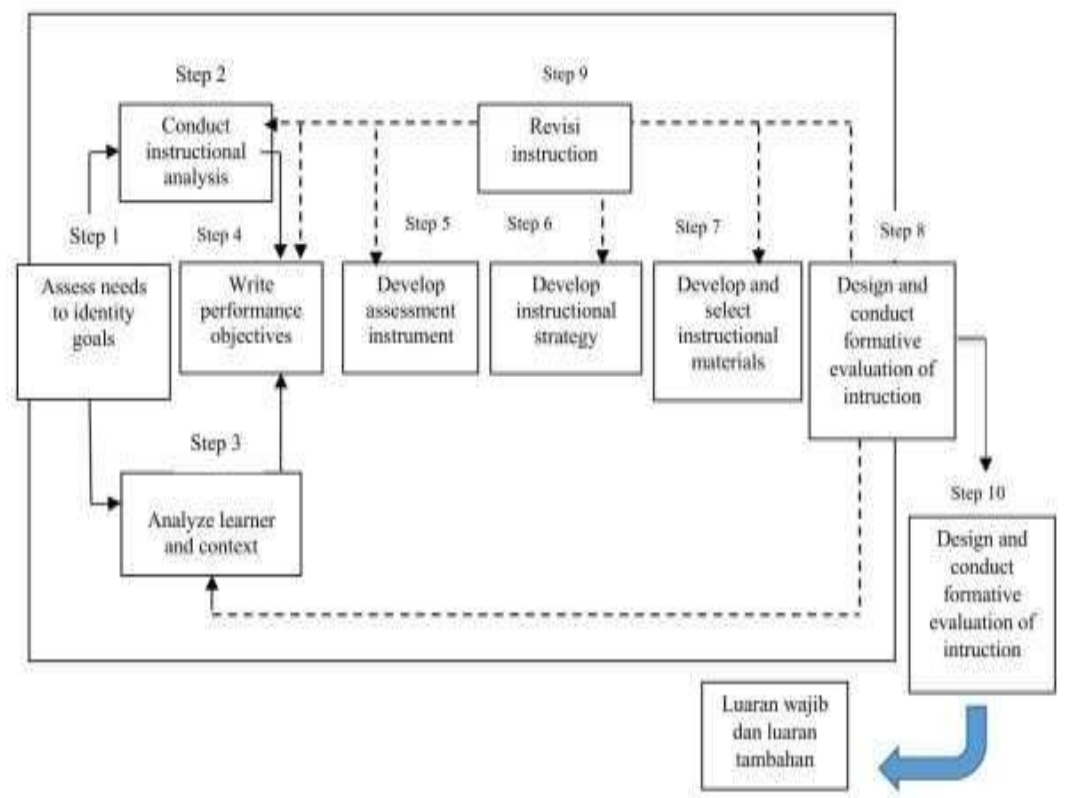


Pada Tahun ke 2, peneliti menggunakan penelitian pengembangan yaitu mengembangkan aplikasi layanan bimbingan dan konseling online berbasis android yang mengacu pada model pengembangan Dick dan Carey [24]. Penelitian dan pengembangan merupakan sebuah proses yang digunakan mengembangkan dan memvalidasi produk di mana temuan hasil penelitian digunakan untuk merancang produk dan prosedur yang secara sistematis diuji, dievaluasi, dan direvisi hingga memenuhi kriteria efektivitas, kualitas, atau standar yang ditentukan

Selanjutnya pada tahun ke 3 peneliti menggunakan uji produk menggunakan uji alpha dan uji beta untuk mengukur keberhasilan serta hubungan antar variable. Dengan demikian akan diketahui signifikansi keberhasilan masing-masing hubungan variable sehingga dapat memberikan rekomendasi dan solusi bagi penentu kebijakan pendidikan di kabupaten Sidoarjo. Pengujian alpha digunakan dalam proses pengembangan yang bertujuan agar system yang dikembangkan terhindar dari kegagalan aplikasi. Pengujian beta merupakan penelitian tahap akhir yang menempatkan aplikasi pada calon pengguna sebenarnya untuk mendeteksi setiap kekurangan atau masalah dari perspektif pengguna akhir.

Subyek dalam penelitian ini adalah siswa-siswi SMP kelas VII, VII, dan IX, serta siswa SMA kelas X, XI, dan XII di 4 kecamatan, Kabupaten Sidoarjo. Adapun pertimbangan penentuan sekolah tersebut dalam penelitian ini antara lain: a) kesediaan kerjasama dengan pengawas pada Dinas Pendidikan, b) kesediaan kepala sekolah berkolaborasi dalam pengembangan aplikasi layanan 
bimbingan konseling online berbasis android, b) antusias dan motivasi guru bagi peningkatan kualitas layanan bimbingan konseling online di sekolah, c) kondisi pandemic COVID-19 berdampak pada keterbatasan melaksanakan layanan bimbingan konseling tatap muka, dan d) lokasi sekolah memudahkan komunikasi berkolaborasi sehingga dapat dihasilkan produk yang sesuai dengan kebutuhan dan kondisi sekolah.

\section{Tahun ke-3}

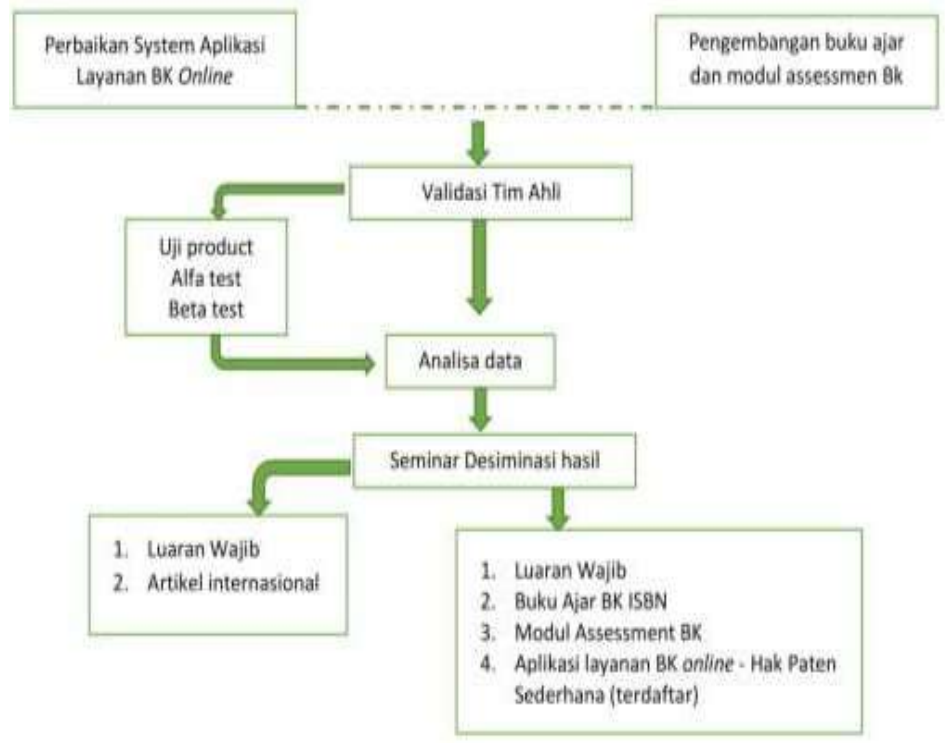




\section{Motivasi Berprestasi}

Mengacu pada renstra penelitian UMSIDA, maka diperlukannya inovasi layanan bimbingan konseling online berbasis android di masa pandemic COVID-19 untuk membantu siswa dalam membangun kepercayaan dirinya dan meningkatkan motivasi berprestasi akademiknya. Hasil penelitian menunjukkan bahwa seseorang yang memiliki self-efficacy rendah cenderung kesulitan menyelesaikan tugas dan

permasalahannya, berbeda dengan yang memiliki self efficacy tinggi, cenderung lebih mudah beradaptasi memiliki keyakinan dan diri yang kuat dalam

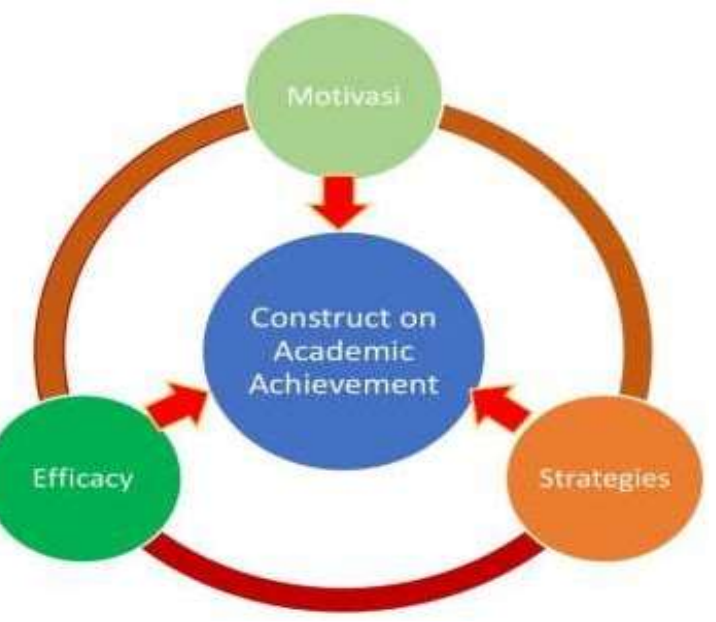
mengatasi permasalahannya (Yusuf, 2011).

Self-efficacy dapat membantu siswa mengembangkan kemampuan terbaiknya. Motivasi juga menjadi salah satu faktor penting untuk mencapai prestasi akademis yang optimal. Berikut menunjukkan adanya hubungan linier antara self-eficacy dengan motivasi berprestasi peserta didik di sekolah.

Gambar tersebut diatas, menunjukkan bahwa ada hubungan langsung maupun tidak langsung antara self- efficacy, motivasi berprestasi, dan strategi belajar mandiri terhadap prestasi akademik peserta didik. Motivasi berprestasi merupakan bentuk 
usaha siswa untuk dapat mengoptimalkan potensinya. Faktor pendorong berprestasi terdiri dari faktor internal dan eksternal. Salah satu faktor internal yang mempengaruhi motivasi berprestasi tersebut adalah self-efficacy. Dengan demikian dapat dipahami bahwa untuk meningkatkan motivasi berprestasi, diperlukan self efficacy yang baik. Pemberian bantuan layanan bimbingan dan konseling yang optimal dapat mmbantu meningkatkan self-efficacy dan motivasi berprestasi dengan siswa mampu menerapkan strategi belajarnya yang efektif. Hasil riset menunjukkan adanya hubungan kausalitas antara dinamika motivasi dengan tingkat kesejahteraan/kenyamanan lingkungan belajarnya. $\mathrm{Hal}$ ini menunjukkan perlunya guru dan praktisi pendidikan untuk mengidentifikasi siswa dan mendukung keterlibatan akademik mereka dengan penataan lingkungan belajar yang aman dan nyaman bagi setiap pebelajar sehingga mampu mengoptimalkan berbagai potensi yang mereka miliki.

\section{Komunikasi Via Internet}

Hasil survey menunjukkan dari jumlah total penduduk Indonesia 262 juta jiwa, hampir setengahnya yakni 143, 26 atau 54, $68 \%$ adalah pengguna internet aktif. Pengguna internet di Indonesia ini menempati peringkat ke-5 setelah Cina, India, USA, dan Brazil. Teknologi informasi yang semakin berkembang saat ini menuntut pembenahan pada pola layanan bimbingan konseling yang dapat dilakukan guru dan siswa dimanapun, dan kapanpun melalui akses internet (Hernawati et al., 2018), dan tetap menjaga privasi klien. 
Di masa pandemic COVID-19, layanan bimbingan konseling SMP \& SMA di Kabupaten Sidoarjo tidak memungkinkan diterapkan layanan dengan system tatap muka. Oleh karenanya perlu inovasi layanan bimbingan dan konseling yang menggunakan berbagai platform sosial interaktif PC, PDA, tablet, dan telepon sebagai media yang memfasilitasi layanan jarak jauh tersebut (Koper, 2014), yang terkoneksi dengan Internet of Things (IOT), dalam bentuk layanan cybercounselling [8]. Hasil riset menunjukkan layanan bimbingan konseling online terbukti efektif meningkatkan prestasi belajar siswa. Layanan bimbingan dan konseling online berbasis android yang mampu memfasilitasi kebutuhan, kenyaman dan kerahasiaan penggunanya.

Layanan berbasis cybercounselling yang selama ini banyak dikembangkan negara-negara maju di dunia internasional memiliki banyak kelebihan karena melibatkan penggunaan media elektronik sehingga dapat menjamin kerahasiaan kliennya. Inovasi layanan jarak jauh yang bersifat online tentunya harus mempertimbangkan desain, instruksi dan teknik penyampaian yang memperhatikan unsur estetika. Untuk itu inovasi yang dikembangkan harus dapat menciptakan dan mempertahankan setting belajar yang mengutamakan multi indera yang holistic sehingga masing-masing individu terfasilitasi dengan layanan yang diberikan.

Berikut alur tahapan model MCO yang akan dikembangkan sehingga dapat membantu memudahkan layanan bimbingan dan konseling siswa di sekolah. 


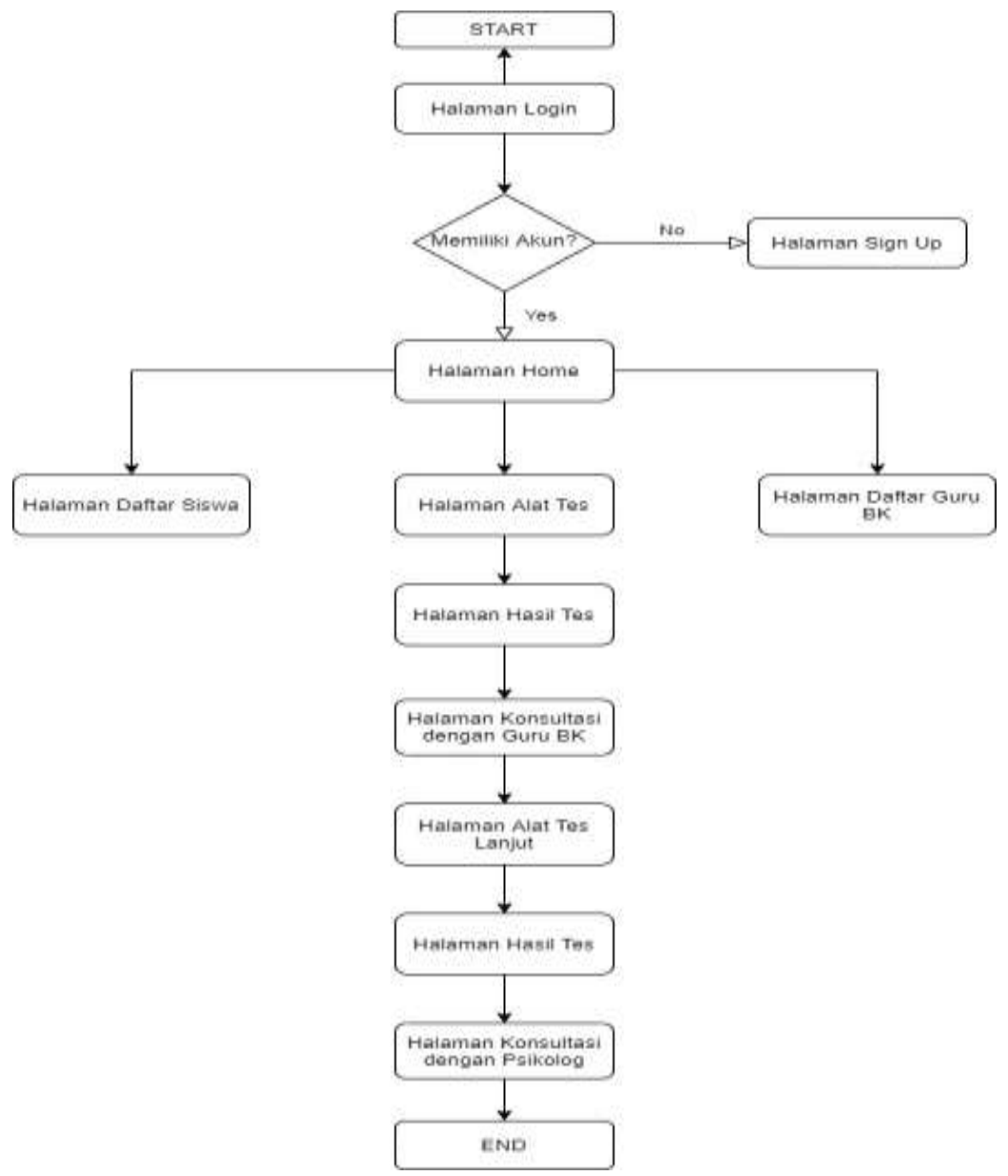


Proses Instalasi Aplikasi MCO

(Mobile Counselling Online)

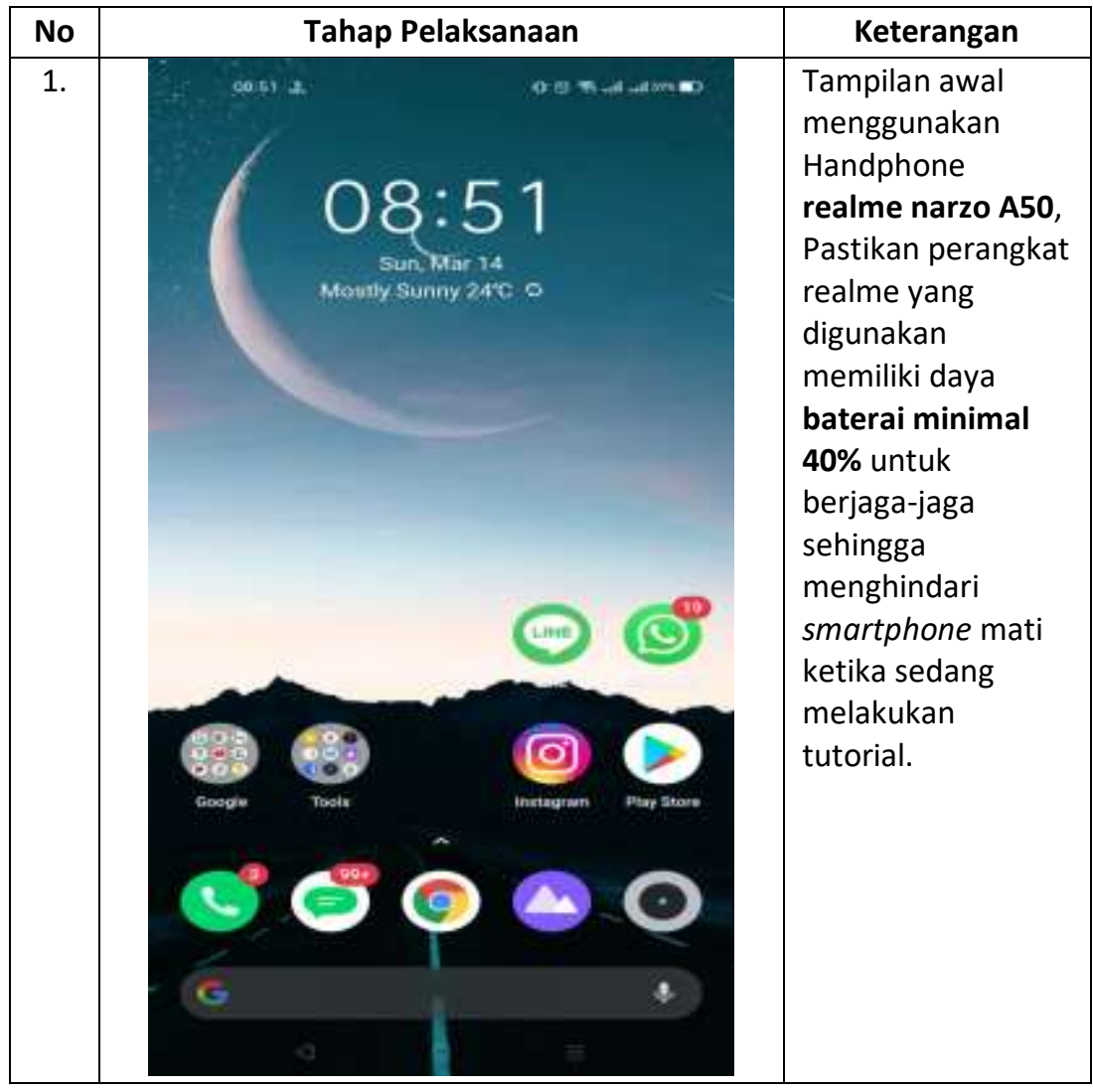




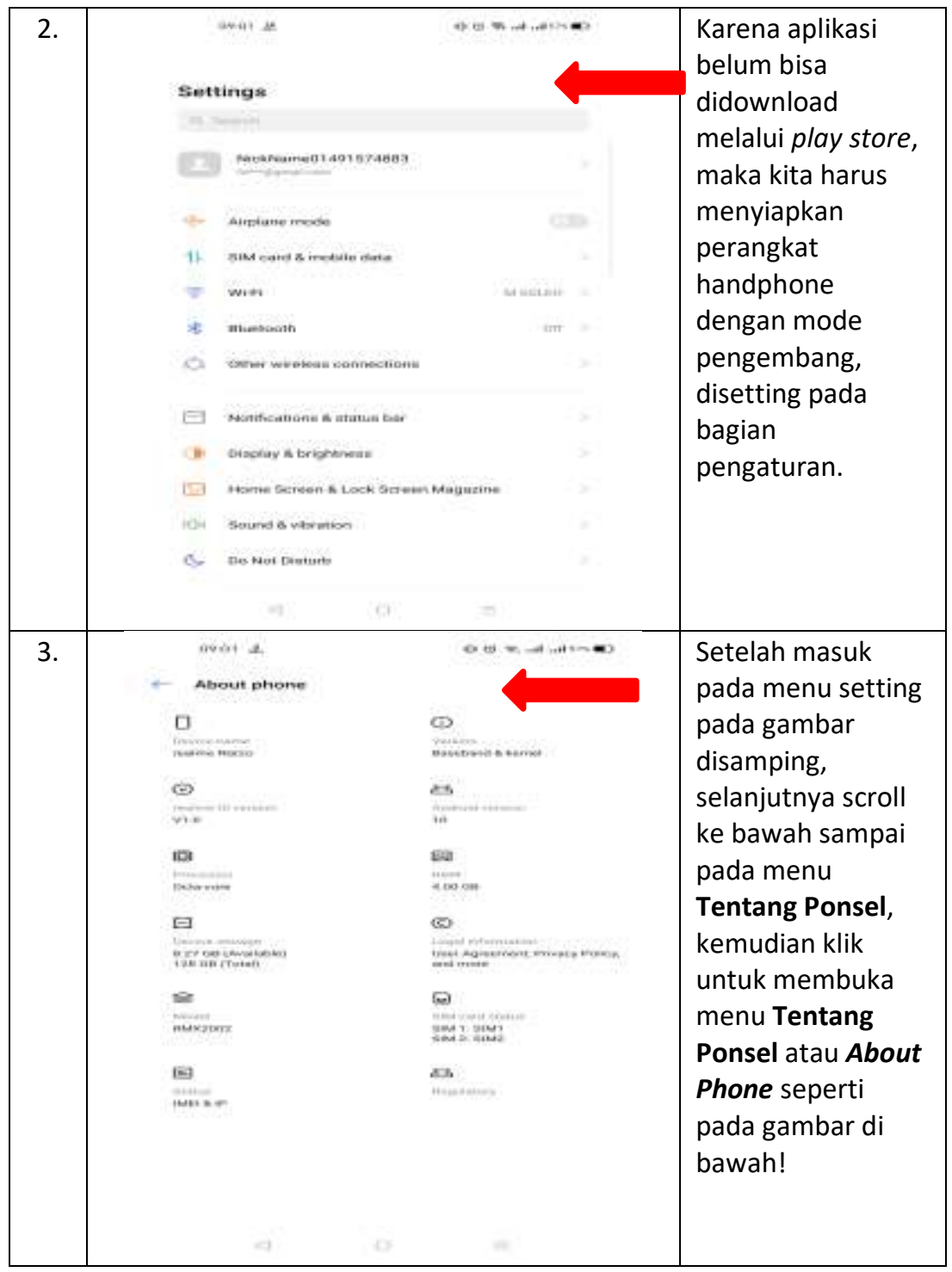




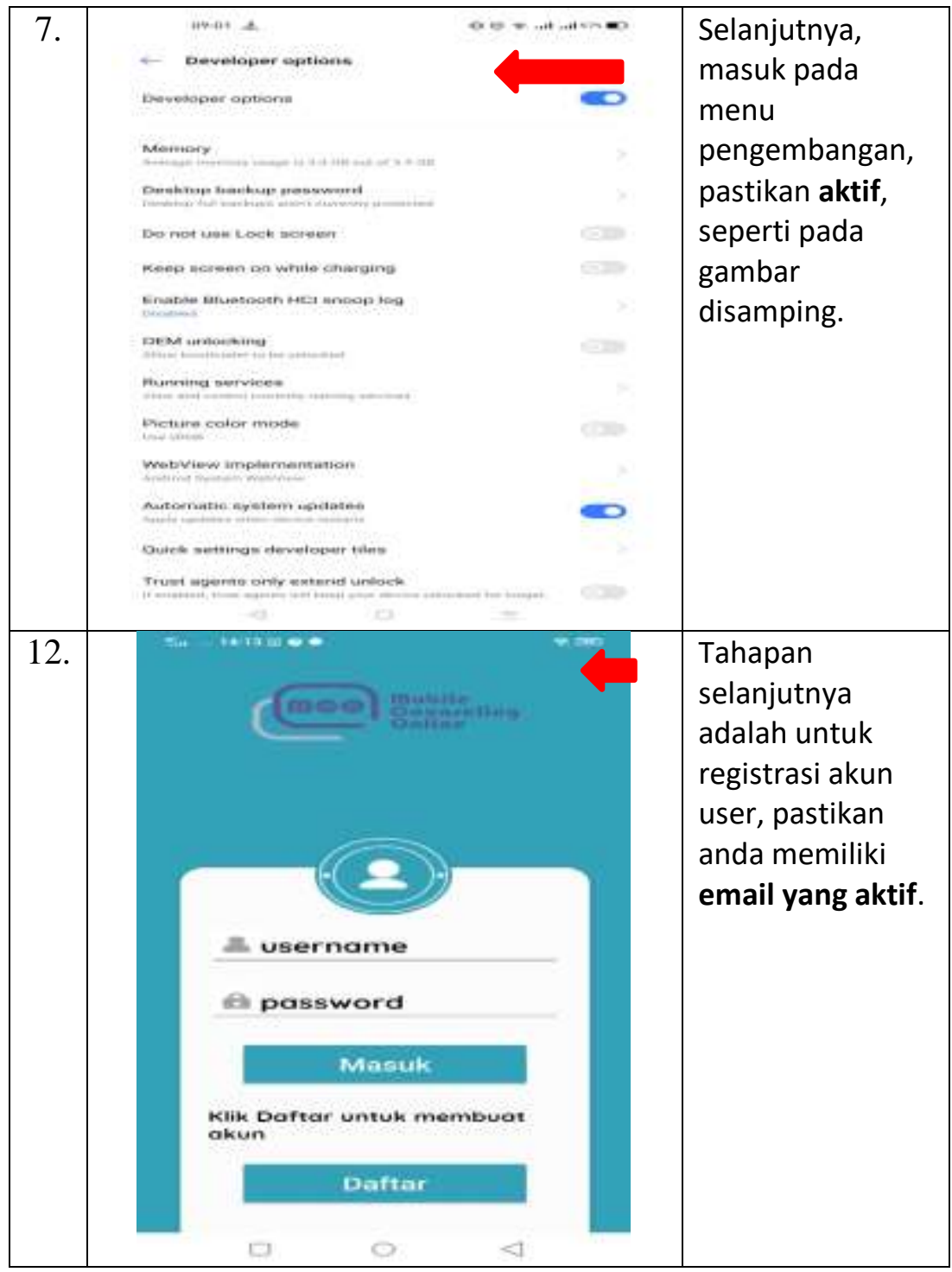




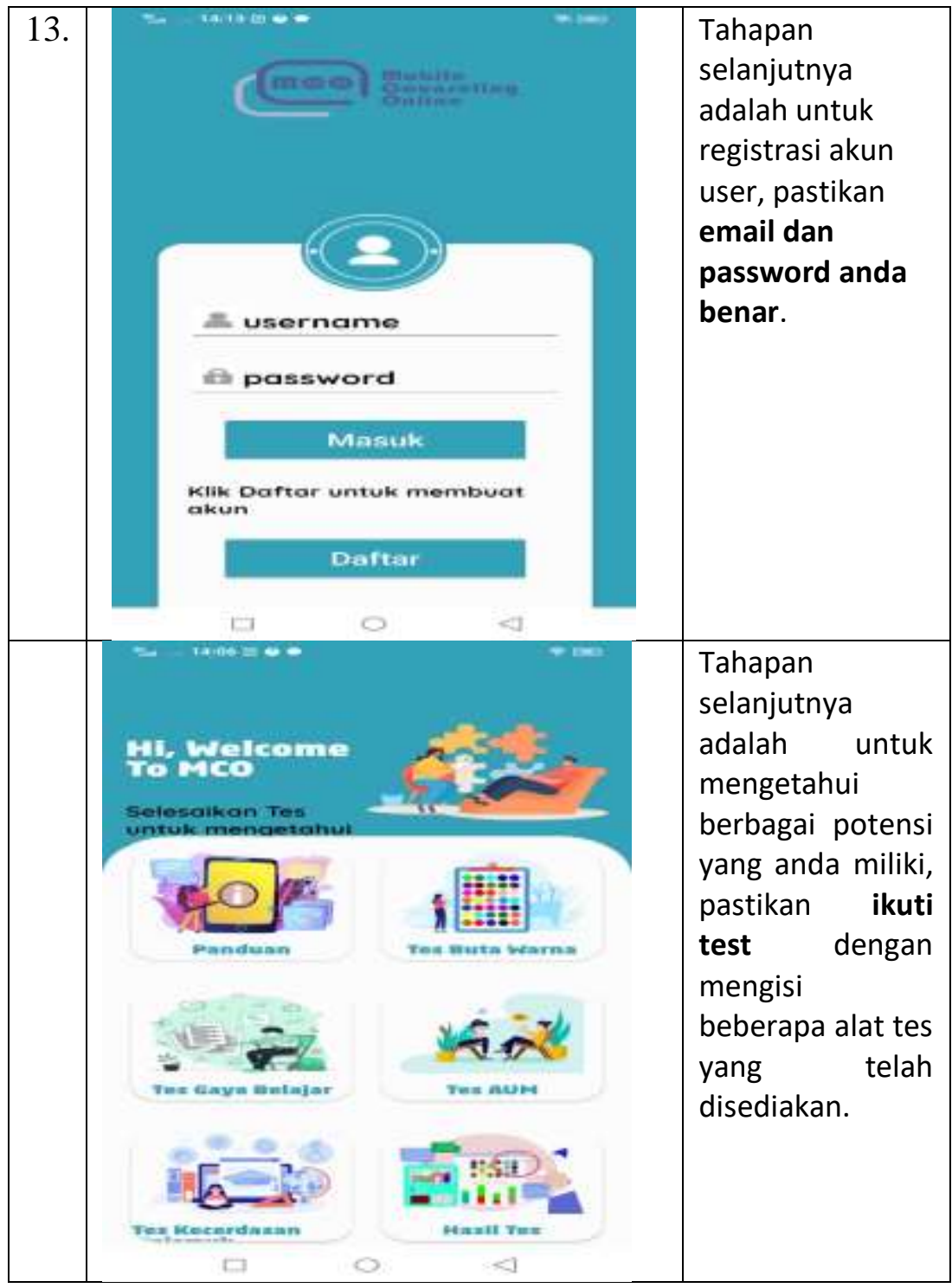




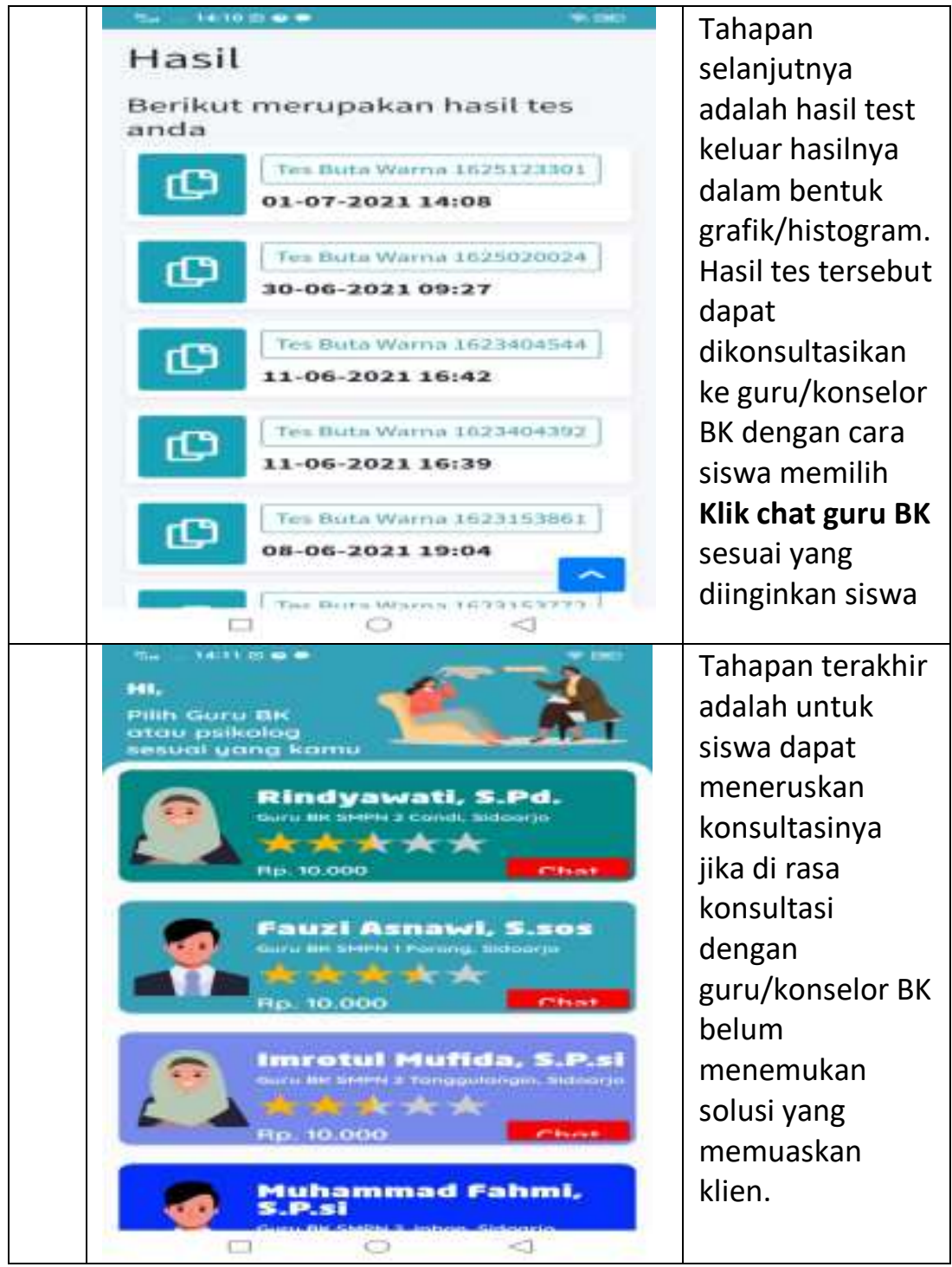


Layanan berbasis cybercounselling yang selama ini banyak dikembangkan negara-negara maju di dunia internasional memiliki banyak kelebihan karena melibatkan penggunaan media elektronik sehingga dapat menjamin kerahasiaan kliennya. Inovasi layanan jarak jauh yang bersifat online tentunya harus mempertimbangkan desain, instruksi dan teknik penyampaian yang memperhatikan unsur estetika. Untuk itu inovasi yang dikembangkan harus dapat menciptakan dan mempertahankan setting belajar yang mengutamakan multi indera yang holistic sehingga masingmasing individu terfasilitasi dengan layanan yang diberikan.

Setiap peserta didik tentunya memiliki karakteristik dan tipe gaya belajar berbeda-beda. Ada tiga macam gaya belajar yang dimiliki oleh setiap individu namun prosentase yang dimiliki masing- masing siswa adalah tidak sama, mulai dari gaya belajar visual. auditorial dan kinestetik. Berbagai faktor yang menjadi penyebab rendahnya kualitas pendidikan, salah satu penyebabnya adalah kualitas guru dan metode yang digunakannya tidak tepat. Guru cenderung menggunakan metode yang sama untuk setiap siswa. Strategi mengajar seperti ini tentu tidak bisa mengakomodir kebutuhan setiap siswa yang memiliki berbagai keunikan dan tipe gaya belajar yang berbeda.

Hasil penelitian menunjukkan penggunaan mobile seamless media terintegrasi pada nilai-nilai Islam dan sains terbukti efektif meningkatkan motivasi dan hasil belajar siswa di sekolah [18]. Oleh karenanya diperlukan penerapan tes gaya 
belajar untuk memahamkan gaya belajar masing-masing siswa [19]. Hasil penelitian menunjukkan adanya peningkatan prestasi belajar siswa pada mata pelajaran Matematika dengan pola pengajaran guru menggunakan pendekatan multiple intelegence atau kecerdasan majemuk para siswanya [20]. Pengenalan potensi diri sangat penting bagi siswa agar mereka mampu menjawab permasalahannya sesuai karakteristik yang dimilikinya. Kemampuan merancang strategi belajar bagi tiap individu adalah tidak sama bagi setiap siswa, untuk itu siswa dapat dilibatkan merancang strategi belajar efektif sesuai potensinya. 


\section{Referensi}

Abu, Lukman; Mokhtar, Mahani; Hassan, Z. (2015). How to Develop Character Education of Madrassa Students in Indonesia. Journal of Education and Learning., 9(1), 79-86.

de Ruiter, J. A., Poorthuis, A. M. G., \& Koomen, H. M. Y. (2019). Relevant classroom events for teachers: A study of student characteristics, student behaviors, and associated teacher emotions. Teaching and Teacher Education, 86, 102899. https://doi.org/10.1016/j.tate.2019.102899

Fahyuni, E. (2018). Bimbingan dan Konseling Islami Di Sekolah. Umsida Press.

Fahyuni, E. et al. (2020). Modul Aplikasi Alat Tes Bimbingan dan Konseling. Umsida Press.

Fahyuni, E. F., Akbar, D., Hadi, N., \& Haris, M. I. (2020). Model aplikasi cybercounselling Islami berbasis website untuk meningkatkan self-regulated learning siswa SMA. Inovasi Teknologi Pendidikan, 7(1), 93-104.

Gozali, A. (2020). Bimbingan dan konseling berbasis teknologi informasi pada masa PSBB ( Pembatasan Sosial Berskala Besar ). Jurnal Bimbingan Konseling Pendidikan Islam Coution: Journal of Counselling and Education Layanan, 1(2), 36-49.

http://journal.bungabangsacirebon.ac.id/index.php/coution/arti cle/view/117

Hernawati, L., Sugiarto, D., Purwanto, E., \& Awalya, A. (2018). The Effectiveness of Cyber Counselling Service to Enhance Student Performance in Statistics. 247(Iset), 302-306. https://doi.org/10.2991/iset-18.2018.63 
Kinzel, H. (2016). Industry 4 . 0 - Where does this leave the Human Factor? 27th Annual Conference of Human Dignity and Humiliation Studies, September, 0-11. http://www.cujucr.com/downloads/Individual Articles/15/vol15 Holger Kinzel.pdf

Koper, R. (2014). Conditions for effective smart learning environments. Smart Learning Environments, 1(1), 1-17. https://doi.org/10.1186/s40561-014-0005-4

Putri, V. D. (2020). Layanan Bimbingan dan Konseling Daring Selama Masa Pandemi COVID-19. Jurnal Bimbingan Konseling Pendidikan Islam, 1(2), 7-16.

Rahman, S. R. (2020). Pembelajaran Online di Tengah Pandemi Covid-19. Indonesian Journal of Educational Science (IJES), 02(02), 81-89.

Schleicher, A. (2012). Preparing Teachers and Developing School Leaders for the 21st Century: Lessons from around the World. OECD Publishing.

Sugiarti, Y. (2020). Penerapan E-Konseling Berbasis Whatsapp dalam Meningkatkan Kepercayaan Diri pada Peserta Didik SMK Negeri 5 Banjarmasin. Jurnal Sipatokkong BPSDM Sulawesi Selatan, 1(2), 137-142.

Yusuf, M. (2011). The impact of self-efficacy, achievement motivation, and self-regulated learning strategies on students' academic achievement. Procedia - Social and Behavioral Sciences, 15, 2623-2626.

https://doi.org/10.1016/j.sbspro.2011.04.158 


\section{KUMPULAN INSTRUMEN BK}

1. Tes Alat Ungkap Masalah (AUM)

2. Tes SSCT

3. Tes BDI (Becks Depression Inventory)

4. Tes PET (Personality Eysenck)

5. Tes Gaya Belajar

6. Tes Angket Berpikir Positif

7. Tes Kecerdasan Majemuk 


\section{$\underline{\text { Tes Alat Ungkap Masalah (AUM) }}$}

\section{Petunjuk :}

1. Dibawah ini ada bermacam - macam masalah, bila masalah ini sesuai dengan kondisi yang pernah di alami atau yang sedang anda alami, maka lingkarilah pada nomornya dilembar jawab yang tersedia.

2. Isilah dengan sejujur - jujurnya, tidak perlu khawatir.

Pengisian dengan sejujur - jujurnya akan sangat membantu kami dalam menganalisa masalah dan mencari solusi atau jalan keluar ynag tepat, sehingga sesuai dngan yang kita harapkan.

\section{KESEHATAN}

1. Badan terlalu kurus, atau terlalu gemuk

2. Warna kulit kurang memuaskan

3. Berat badan terus berkurang, atau bertambah.

4. Badan terlalu pendek, atau terlalu gemuk.

5. Secara jasmaniah kurang menarik.

6. Belum mampu memikirkan dan memilih pekerjaan yang akan dijabat

7. Belum mengetahui bakat diri sendiri untuk jabatan/pekerjaan apa.

8. Kurang memiliki pengetahuan yang luas tentang lapangan pekerjaan dan seluk beluk jenis-jenis pekerjaan.

9. Ingin memperoleh bantuan dalam mendapatkan pekerjaan sambilan untuk melatih diri bekerja sambil sekolah.

10. Khawatir akan pekerjaan yang dijabatnya nanti; jangan-jangan memberikan penghasilan yang tidak mencukupi.

11. Terpaksa atau ragu-ragu memasuki sekolah ini.

12. Meragukan kemanfaatan memasuki sekolah ini.

13. Sukar menyesuaikan diri dengan keadaan sekolah.

14. Kurang meminati pelajaran atau program yang diikuti.

15. Khawatir tidak dapat menamatkan sekolah sesuai yang direncanakan.

16. Fungsi dan atau kondisi kesehatan mata kurang baik.

17. Mengalami gangguan tertentu karena cacat jasmani. 
18. Fungsi dan atau kondisi kesehatan hidung kurang baik.

19. Kondisi kesehatan kulit sering terganggu.

20. Gangguan pada gigi

\section{KEADAAN PENGHIDUPAN}

21. Uang saku pemberian orang tua tidak mencukupi

22. Kekurangan buku karena malas membeli

23. Ayah pensiun dan tidak bekerja lagi

24. Ayah sudah mninggal dan ibu tidak bekerja

25. Ibu terpaksa harus bekerja karena ekonomi tidak mencukupi

26. Ibu bekerja sedangkan ayah tidak

27. Banyak adik yang menjadi tanggungan dalam keluarga

28. Tidak tahu harus bagaimana untuk menambah biaya sekolah

29. Sering pinjam uang kepada teman atau orang lain

30. Tidak ada keinginan untuk melanjutkan sekolah

31. Ingin mempunyai kamar senidri

32. Penerangan lampu di rumah kurang mencukupi

33. Iuran sekolah sering terlambat dibayar

34. Sering mengendarai mobil sendiri ke sekolah

35. luran sekolah terlalu tinggi

36. Orang tua tidak punya penghasilan tetap

37. Tidak ada uang untuk membeli pakaian

38. Ayah dan ibu bercerai dan saya ikut ibu

39. Saya mengharapkan agar mendapat beasiswa

40. Tinggal atau ikut dengan saudara

\section{REKREASI dan HOBBY}

41. Fampir tidak mempunyal waktu untuk bermain

42. Keinginan untuk rekreasi sering terhalang

43. Gemar melukis tetapi dilarang oleh orang tua

44. Waktu libur harus mngikuti les privat

45. Suka berolah raga tetapi tidak ada kesempatan

46. Tidak suka berolah raga

47. Hobby selalu mengganggu belajar

48. Lebih suka buku-buku hiburan daripada buku-buku sekolah 
49. Saya senang nonton film di gedung film

50. Gemar melukis tetapi tidak mempunyai waktu

51. Tidak bisa memanfaatkan waktu senggang

52. Salah seorang anggota keluarga selalu menghalang-halangi hobby saya

53. Ingin belajar menari atau main sandiwara tetapi tidak diijinkan

54. Kesenangan membaca majalah atau komik sering menghabiskan waktu belajar

55. Habis waktu nonton tv

56. Karena sibuk orang tua tidak pernah mengajak rekreasi keluar kota

57. Hampir setiap minggu orang tua mengajak rekreasi keluar kota

58. Senang menyanyi tetapi tidak ada kesempatan

59. Kedatangan teman menghabiskan wsktu belajar saya

60. Waktu belajar habis untuk bermain.

IV. KEHIDUPAN SOSIAL

61. Tidak senang bermain dalam kelompok

62. Sering gagal dalam mencari teman

63. Merasa tidak disenangi kawan-kawan di luar sekolah

64. Suka bergaul

65. Tidak berminat dalam berorganisasi

66. Tidak terlalu aktif dalam berorganisasi

67. Sukar menyesuaikan diri

68. Merasa mudah tersinggung

69. Takut bergaul dengan kakak kelas

70. Tidak pernah jadi pemimpin

71. Tidak berani menemukakan suatu pndapat

72. Sukar menerima kekalahan

73. Sering bertentangan dengan orang lain

74. Selalu ingin berkuasa dalam pergaulan

75. Bingung bial berhadapan ddengan orang banyak

76. Mudah merasa malu

77. Mudah untuk marah

78. Sering merasa tidak sabar

79. Sering tidak menepati janji 
80. Sering ditegur karena kurang sopan

\section{HUBUNGAN PRIBADI}

81. IIdak suka bergaul dengan orang yang kedudukannya lebih rendah

82. Tidak suka bergaul dengan orang yang kedudukannya lebih tinggi

83. Sering merasa malu bergaul dengan teman jenis kelamin lain

84. Sering merasa iri hati

85. Sukar untuk mendapat teman

86. Tidak suka bertamu

87. Enggan menerima tamu atau teman ke rumah

88. Merasa tidak dihargai teman

89. Sering merasa curiga terhadap orang lain

90. Bersikap kaku dan tidak toleran

91. Bersifat dingin dalam pergaulan

92. Sering menyesali diri sendiri

93. Sering ingin bunuh diri

94. Merasa tidak mempunyai harapan (pesimis)

95. Ingin lebih menarik dan ingin sekali dikagumi

96. Tidak ingin punya sahabat

97. Tidak mempunyai kawan yang akrab

98. Merasa diri saya tidak sebaik orang lain

99. Mempunyai kebiasaan jelek (misalnya menggigit kuku dll )

100. Saya ingin hidup lebih tenang lagi

\section{PERGAULAN atau MUDA - MUDI}

101. Sering melamun memikirkan si dia

102. Tidak bisa belajar kalau belum menelepon si dia

103. Ragu-ragu terhadap pacar

104. Pacar sering mengajak saya jalan-jalan

105. Kesepian karena belum mendapat pacar

106. Iri melihat kawan berpasangan

107. Menggunakan banyak waktu untuk di mall atau diskotik

108. Memilih pacar sulit baginya

109. Mudah mencintai tetapi mudah melepaskan

110. Sering bertepuk sebelah tangan 
111. Sering pulang larut malam

112. Sering diajak atau ditawari teman

113. Sering teman untuk berpacaran

114. Sukar bergaul dengan jenis kelamin lain atau lawan jenis

115. Dilarang berpacaran oleh orang tua

116. Lebih senang pergi sama teman daripada sama keluarga

117. Berpacaran melupakan kebutuhan yang penting sekali

118. Berteman dengan teman sejenis lebih menynangkan daripada teman lawan jenis

119. Merasa lebih menyenangkan berteman dengan lawan jenis

120. Sering melanggar larangan orang tua atau backstreet dalam hal berpacaran

\section{KEHIDUPAN KELUARGA}

121. Saya anak tunggal

122. Tidak hidup bersama kedua orang tua

123. Selalu bertangkar dengan adik ataupun kakak

124. Ayah dan Ibu pulang kerja terlalu malam

125. Tidak pernah bergembira dengan Ayah dan Ibu

126. Pertengkaran Ayah dan Ibu menggangu pikiran

127. Orang tua kurang memperhatikan saya

128. Orang tua terlalu banyak bepergian

129. Orang tua terlalu banyak menuntut

130. Sukar menyesuaikan diri dengan Ayah dan Ibu

131. Meras tidak betah tinggal di rumah

132. Kehidupan di rumah kurang teratur

133. Ingin mengadakan perubahan di rumah

134. Di keluarga kami kurang tolong-menolong

135. Ayah dan Ibu tidak hidup bersama

136. Keluarga kami berantakan

VIII. MASA DEPAN dan CITA - CITA dan PENDIDIKAN atau PEKERJAAN

137. Khawatir tidak bisa mandiri klak

138. Tidak terlalu akan berbuat apa setelah tamat

139. Sulit untuk menentukan cita-cita 
140. Ingin melanjutkan ke perguruan tinggi yang terkenal

141. Ingin mengetahui bakat dan kemampuan yang dimiliki

142. Cita-cita tidak sesuai dengan kemampuan

143. Cita-cita tidak sesuai dengan prestasi belajar

144. Cita-cita tidak disetujui oleh orang tua

145. Cita-cita terganggu oleh hobby

146. Belum mempunyai cita-cita tertentu

147. Tidak ada orang yang membantu mengenali cita-cita saya

148. Cit-cita selalu gagal

149. Mudah terpengaruh oleh cita-cita orang lain

150. Masa depan tidak ditntukan olah usaha saat sekarang

151. Bingung untuk menetukan sekolah lanjutan setelah tamat SLTP nanti

\section{PENYESUAIAN TERHADAP KURIKULUM}

152. Pelayanan di sekolah terlalu berat

153. Pelayanan di sekolah terlalu ringan

154. Enggan mengikuti kegiatan-kegiatan di luar kelas

155. Sulit mengerti isi buku pelajaran

156. Saya merasa takut bila ada mata pelajaran yang akan ulangan

157. Tidak suka belajar

158. Tidak berminat terhadap buku-pelajaran

159. Nilai ulangan sering mendapat nialai rendah

160. Tidak senang belajar bersama

161. Sering mendapat kesukaran bila mendapat tugas $P R$

162. Sukar menangkap dan mengikuti pelajaran fiiska dan matematika

163. Sukar mempelajari pelajaran Biologi

164. Merasa beban pelajaran terlalu berat

165. Merasa pelajaran tidak berguna

166. Sukar mnyesuaikan diri dngan suasana

\section{LAIN-LAIN}

167. Masalah apa yang menurut kamu belum tercantum diatas

168. Masalah-masalah apa yang menurut kamu paling menyulitkan

169. Sukakah kamu meluangkan waktu untuk membicarkan kesulitanmu ? Jika benar dengan siapa? 
NAMA

PETUNJUK PENGISIAN:

Lingkarilah nomor - nomor berikut yang tersedia didalam kolom sesuai dengan pilihan jawaban anda!

\begin{tabular}{|c|c|c|c|c|c|c|c|c|}
\hline $\begin{array}{c}\text { KESEH } \\
\text { ATAN } \\
(1)\end{array}$ & $\begin{array}{c}\mathrm{K} . \\
\text { EKO } \\
\text { NOM } \\
\text { I } \\
(2)\end{array}$ & $\begin{array}{l}\text { REKRE } \\
\text { ASI \& } \\
\text { HOBY } \\
\text { (3) }\end{array}$ & $\begin{array}{c}\text { K. } \\
\text { SOSI } \\
\text { AL } \\
(4)\end{array}$ & $\begin{array}{c}\text { PRIB } \\
\text { ADI } \\
\text { (5) }\end{array}$ & $\begin{array}{c}\text { PERGA } \\
\text { ULAN } \\
\text { (6) }\end{array}$ & $\begin{array}{l}\text { KEL } \\
\text { UAR } \\
\text { GA } \\
\text { (7) }\end{array}$ & $\begin{array}{c}\text { DEP } \\
\text { AN \& } \\
\text { CITA } \\
- \\
\text { CITA } \\
(8)\end{array}$ & $\begin{array}{c}\text { PENYE } \\
\text { SUAIA } \\
\mathrm{N} \\
\text { BELAJ } \\
\text { AR } \\
(9)\end{array}$ \\
\hline 1 & 21 & 41 & 61 & 81 & 101 & 121 & 137 & 152 \\
\hline 11 & 31 & 51 & 71 & 91 & 111 & 131 & 147 & 162 \\
\hline 2 & 22 & 42 & 62 & 82 & 102 & 122 & 138 & 153 \\
\hline 12 & 32 & 52 & 72 & 92 & 112 & 132 & 148 & 163 \\
\hline 3 & 23 & 43 & 63 & 83 & 103 & 123 & 139 & 154 \\
\hline 13 & 33 & 53 & 73 & 93 & 113 & 133 & 149 & 164 \\
\hline 4 & 24 & 44 & 64 & 84 & 104 & 124 & 140 & 155 \\
\hline 14 & 34 & 54 & 74 & 94 & 114 & 134 & 150 & 165 \\
\hline 5 & 25 & 45 & 65 & 85 & 105 & 125 & 141 & 156 \\
\hline 15 & 35 & 55 & 75 & 95 & 115 & 135 & 151 & 166 \\
\hline 6 & 26 & 46 & 66 & 86 & 106 & 126 & 142 & 157 \\
\hline 16 & 36 & 56 & 76 & 96 & 116 & 136 & 143 & 158 \\
\hline 7 & 27 & 47 & 67 & 87 & 107 & 127 & 144 & 159 \\
\hline 17 & 37 & 57 & 77 & 97 & 117 & 128 & 145 & 160 \\
\hline 8 & 28 & 48 & 68 & 88 & 108 & 129 & 146 & 161 \\
\hline 18 & 38 & 58 & 78 & 98 & 118 & 130 & & \\
\hline 9 & 29 & 49 & 69 & 89 & 109 & & & \\
\hline 19 & 39 & 59 & 79 & 99 & 119 & & & \\
\hline 10 & 30 & 50 & 70 & 90 & 110 & & & \\
\hline 20 & 40 & 60 & 80 & 100 & 120 & & & \\
\hline
\end{tabular}

setelah menjawab masing - masing kolom maka jumlahkanlah dimasing - masing kolomnya 


\section{TES SSCT}

Nama

Tanggal

Petunjuk

Di bawah ini ada 60 butir kalimat yang belum lengkap. Bacalah masing - masing dan selesaikanlah dengan mengisikan apa yang pertamatama muncul dalam dirimu. Bekerjalah secepat-cepatnya, bila ada yang dapat kamu kerjakan lingkarilah nomornya dan kembalilah mengerjakannya kemudian.

1. Saya rasa ayahku jarang

2. Meskipun nasib sedang menimpa diriku

3. Saya selalu ingin untuk

4. Bila saya bertugas

5. Bagiku masa depan Nampak

6. Guru-guru saya

7. Saya tahu kalau aneh saya tidak berani

8. Saya rasa teman yang sejati

9. Sewaktu saya kecil

10. Gagasanku yang sempurna 
11. Bila kulihat seorang laki-laki dan wanita bersama-sama

12. Dibandingkan dengan banyak keluarga, keluargaku

13. Dalam pekerjaan, saya baik sekali dengan

14. Ibuku

15. Saya akan melakukan apapun untuk melupakan

16. Andaikata saya ayahku

17. Saya percaya bahwa saya mampu untuk

18. Saya akan berbahagia benar bila

19. Bila orang bekerja untukku

20. Saya berharap untuk

21. Disekolah guru-guruku

22. Kebanyakan teman-temanku tidak tahu bahwa saya takut terhadap

23. Saya tidak menyukai orang

24. Sebelum masuk sekolah saya

25. Saya kira kebanyakan gadis-gadis

26. Keluargaku memperlakukan saya

28. Mereka yang bekerja denganku

29. Ibuku dan saya

30. Kesalahanku yang terbesar adalah 
31. Saya berharap ayahku

32. Kelemahanku yang terbesar adalah

33. Rahasia cita hidupku

34. Orang-orang yang bekerja untukku

35. Suatu hari saya

36. Bila saya melihat kepala sekolah datang

37. Saya ingin mehilangkan takut kepada

38. Orang yang paling saya sukai

39. Andaikata saya kembali muda

40. Saya percaya kebanyakan wanita

41. Bila saya berpacaran

42. Kebanyakan keluarga yang saya kenal adalah

43. Saya senang bekerja dengan orang yang

44. Saya kira kebanyakan ibu-ibu

45. Sewaktu saya muda

46. Saya merasa bahwa ayahku adalah

47. Bila nasib baik menghindariku

48. Dalam memberikan perintah kepada orang lain 
49. Apa yang saya inginkan sekali dari kehidupan

50. Bila saya lebih tua 51. Orang-orang yang saya pandang di atasku

52. Ketakutanku kadang-kadang memaksaku untuk

53. Bila saya sedang tidak ada, teman-temanku

54. Kenangan masa kanak-kanakku yang paling jelas

55. Yang paling sedikit yang kusukai tentang wanita

56. Kehidupan seksku

57. Sewaktu kanak-kanak, keluargaku

58. Orang-orang yang bekerja dengan saya biasanya

59. Saya suka pada ibuku tetapi

60. Yang paling jelek pernah saya lakukan 


\section{Tes BDI (Becks Depression Inventory)}

\section{Petunjuk :}

Pada saat anda mengisi kuesioner ini, bacalah setiap soal seksama dan lingkarilah nomor pada lembar jawaban yang paling mencerminkan apa yang anda rasakan selama beberapa hari ini. Pastikan bahwa anda menjawab semua pertanyaan ini. Jika lebih dari satu jawaban yang cocok untuk anda, maka lingkarilah nomor yang paling tinggi. Jika ragu-ragu tentukanlah mana yang anda rasa paling baik. Jangan sampai ada pertanyaan yang tidak terjawab.

0 . Saya tidak merasa sedih

1. Saya merasa sedih

2. sepanjang waktu saya sedih

3. Saya sedih dan tidak bahagia

0. Saya tidak berkecil hati mengenai masa depan saya

1. Saya merasa kecil hati tentang masa depan

2. Saya merasa tidak ada yang saya harapkan

3. Saya merasa masa depan saya tanpa harapan

0. Saya tidak menganggap diri saya gagal

1. Saya merasa telah gagal dari kebanyakan orang

2. Saat saya menengok masa lalu, hanya kegagalan

3. Saya merasa seorang yang gagal total

0. Saya memperoleh banyak kepuasan dari hal-hal yang saya lakukan, sama seperti sebelumnya

1. Saya tidak menikmati yang saya rasakan dulu

2. Saya tidak memperoleh kepuasan sejati

3. Saya tidak puas dan bosan dengan segalanya 
0. Saya tidak terlalu merasa bersalah

1. Saya merasa bersalah di hampir tiap waktu

2. Saya merasa bersalah setiap waktu

3. Saya merasa bersalah di sepanjang waktu

0. Saya tidak merasa seolah saya sedang dihukum

1. Saya merasa mungkin saya sedang dihukum

2. Saya pikir saya akan dihukum

3. Saya merasa bahwa saya sedang dihukum

0. Saya tidak merasa kecewa terhadap diri saya

1. Saya agak kecewa terhadap diri saya sendiri

2. Saya kecewa terhadap diri saya sendiri

3. Saya membenci diri saya sendiri

0. Saya tidak merasa lebih buruk daripada orang lain

1. Saya cela diri saya karena kelemahan saya

2. Saya menyalahkan diri saya sepanjang waktu

3. Saya menyalahakan diri saya untuk semua hal

0. Saya tidak punya pikiran sedikitpun bunuh diri

1. Saya ingin bunuh diri

2. Saya kecewa terhadap diri saya sendiri

3. Saya akan bunuh diri jika ada kesempatan

0. Saya tidak lebih banyak menangis

1. Saya lebih banyak menangis daripada sebelumnya

2. Saya sekarang menangis sepanjang waktu

3. Biasanya saya mampu menangis, namun kini saya tidak lagi bisa menangis walaupun saya menginginkannya

0 . Saya tidak terganggu berbagai hal

1. kini saya sedikit lebih parah dibandingkan biasanya

2. Saya terganggu di sebagian besar waktu saya 
3. Kini saya merasa jengkel sepanjang waktu

0. Saya tidak kehilangan minat terhadap orang lain

1. Saya agak kurang berminat terhadap orang lain

2. Saya kehilangan minat saya terhadap orang lain

3. Saya telah kehilangan minat saya pada orang lain

0. Saya mengambil keputusan hamper sama baiknya dengan yang biasanya saya lakukan

1. Saya menunda mengambil keputusan

2. Saya mengalami kesulitan besar dalam mengambil keputusan daripada sebelumnya

3. Saya tidak dapat mengambil keputusan lagi

0. Saya tidak merasa keadaan saya buruk

1. Saya kuatir tampak tua dan tidak menarik

2. Saya merasa ada perubahan yang permanent dalam penampilan saya sehingga membuat saya nampak tidak menarik

3. Saya yakin bahwa saya nampak jelek

0. Saya dapat bekerja dengan baiknya

1. Saya membutuhkan usaha ekstra memulai sesuatu

2. Saya harus memaksa diri untuk melakukan sesuatu

3. Saya tidak mampu melakuakan apapun lagi

0. Saya dapat tidur seperti biasanya

1. Tidur saya tidak nyenyak seperti biasanya

2. Saya bagun 1-2 jam lebih awal dari biasanya dan merasa sukar sekali untuk bisa tidur kembali

3. Saya bangun beberapa jam lebih awal daripada biasanya serta tidak dapat tidur kembali 
0. Saya tidak merasa lebih lelah dari biasanya

1. Saya merasa lebih mudah lelah dari biasanya

2. Saya merasa lelah setelah melakukan apa saja

3. Saya terlalu lelah untuk melakukan apapun

0. Nafsu makan saya tidak lebih buruk dari biasanya

1. Nafsu makan saya tidak sebaik biasanya

2. Nafsu makan saya kini jauh lebih buruk

3. Saya tidak memiliki nafsu makan lagi

0. Berat badan saya tidak turun banyak

1. Berat badan saya turun lebih dari 5 kilogram

2. Berat badan saya turun lebih dari 10kilogram

3. Berat badan saya turun lebih dari 15 kilogram

0. Saya tidak cemas mengenai kesehatan saya

1. Saya cemas mengenai masalah fisik seperti masalah sakit dan tidak enak badan atau perut mual dan sembelit

2. Saya cemas mengenai masalah fisik

3. Saya cemas mengenai masalah fisik saya sehingga tidak dapat berpikir tentang hal yang lainnya

0. Saya tidak minat terhadap lawan jenis

1. Saya kurang berminat terhadap lawan jenis

2. Saya sangat kurang berminat terhadap lawan jenis

3. Saya telah kehilangan minat lawan jenis 
38BN 978-623-6292-12-9 (PDF)

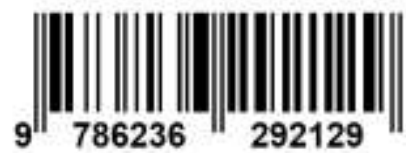

